\title{
ACCOMPLISHING COHERENCE IN TALK SHOWS: A COMPARISON BETWEEN ENGLISH AND INDONESIAN
}

\author{
Yana Shanti Manipuspika \\ Universitas Brawijaya \\ email: yana.manipuspika@gmail.com
}

\begin{abstract}
This paper tried to show how conversational coherence is achieved within talk shows, what strategies used by both host and interviewee to achieve coherence collaboratively. It was shown that in both English and Indonesian talk shows, conversational activity of asking questions can be employed to measure a coherence of a stretch of conversation. Question-answer adjacency pairs can provide the framework through which coherence is achieved, and they have two possibilities to be agreed or disagreed with. This is clear from the English talk show instead of the Indonesian one. The way speakers taking turn and the occurrence of overlap within the sequence of conversation can also determine mutual understanding among the participants. However, the Indonesian talk show offers a longer answer pair compared with the English one. Both talk shows, in fact, share the similar indicators and use similar strategies in order to achieve coherence across the talk show sessions. Speaker's hesitation is found more in the Indonesian talk show instead of the English one. Another marker of coherence, overlap onset, also occurs a lot in both talk shows. The way speakers (host and interviewee) maintain the topic throughout the talk supports the notion that mutual understanding is successfully achieved. Meanwhile, culture is considered not too influential in determining different ways of maintaining the flow of the talk. Both talk shows use similar patterns with no significant difference in terms of culture. They differ only in the level of conversational devices used which is related to language use instead of cultural background.
\end{abstract}

Keywords: coherence, adjacency pairs, turn-taking, talk shows

Abstrak: Studi ini mencoba menunjukkan bagaimana koherensi percakapan dicapai dalam talk show, strategi apa yang digunakan oleh pembawa acara serta tamu yang diwawancarai untuk mencapai koherensi secara kolaboratif. Hal ini menunjukkan bahwa dalam talk show berbahasa Inggris maupun Indonesia, cara mengajukan pertanyaan dapat digunakan untuk mengukur koherensi dalam percakapan. Pasangan bersesuaian (adjacency pairs) dapat memberikan kerangka di mana koherensi dicapai, hal ini lebih jelas terlihat dalam talk show berbahasa Inggris. Cara mengambil giliran tutur dan terjadinya tumpang tindih dalam urutan percakapan juga dapat menentukan pemahaman di antara penutur. Dalam talk show berbahasa Indonesia, pemberian jawaban yang mengandung keragu-raguan lebih banyak ditemukan. Kedua talk show menunjukkan indikator yang sama dan menggunakan strategi yang sama untuk mencapai koherensi dalam sesi tanya jawab. Tumpang tindih kalimat (overlap onset), juga banyak ditemukan dalam kedua talk show. Cara pembawa acara dan tamu yang diwawancarai untuk mempertahankan topik pembicaraan menunjukkan bahwa saling pengertian berhasil dicapai. Sementara itu, kebudayaan dianggap tidak terlalu berpengaruh dalam menentukan perbedaancara dalam mempertahankan alur pembicaraan. Pada kedua talk show tidak ditemukan perbedaan yang signifikan dalam hal budaya. Mereka hanya berbeda dalam tingkat perangkat percakapan yang digunakan yang berkaitan dengan penggunaan bahasa bukan latar belakang budaya.

Kata kunci: koherensi, pasangan bersesuaian, giliran tutur, talk shows 
The distinction between coherence and cohesion in a discourse (text) is relatively obscure; however, it is central to differentiate between the two in the analysis of the discourse. For decades, discourse-level studies of language have dealt with utterances that exceed the range of a sentence. Discourse studies, regarding language as being influenced by the situation in which it is used, with major concern of describing language use as a social phenomenon and establishing causal links between language and society, deal with individual language use in relation to its social implications and studies of conversational structure which observe how spoken discourse proceeds and transmits meaning among interlocutors (Wardhaugh, 1986; Coulmas, 1997).

A substantial number of studies in the field of discourse analysis have shown that this branch of applied linguistics study is expanding. Talk shows, in addition, are starting to emerge as one focus of research since the shows represent the verbal interaction in a social context (Morizumi, 1997; Ilie, 1999; Hutchby, 2006; Takagi, 2008). Conversation analysis then comes out as an analytical perspective explaining that in their turns at talk, speakers conduct social actions of various kinds; and that all aspects of linguistic production are organized in terms of a turn's position in a sequence of turns or action (Drew \& Heritage, 1992; Ten Have, 1999).

As a form of verbal interaction, a talk show needs to form a coherent discourse. A number of scholars including Fairclough (1992) and Hutchby (1995) have given specific attention to this particular type of media communication; however, the correlation between discursive and linguistic features that distinguish talk show from other dialogic institutional discourse has not been so widely discussed (Ilie, 1999). A talk show has patterns of communicative and social behavior which can be associated with more than one discourse type (Tolson, 2001). In a televisual discourse like talk show and news interviews, the direct look of the person participating within the discourse is allowed to be directed toward those who are watching. In this case, a television talk show will need at least four elements: the talk show host, the guest(s) being interviewed, the studio audience which the host might get some responses from, and home audience.

Ilie (1999) mentioned that a talk show is a kind of entertainment program in which each participant within the talk show discourse has his/her own role which results in pronoun shifts, metalinguistic utterances, or the feedback replies. The interactional conversation will determine how culture affects the flow of the spoken discourse.

Despite the fact that there have been studies using analyzing talk show conversation, very few studies have been conducted on the aspect of coherence within spoken discourse. The present study focuses on the coherence aspect of the talk show as a mixed of broadcast discourse, with specific reference to two different talk shows. One is an English-spoken talk show, and the other one is an Indonesianspoken talk show. The talk show which is primarily the subject of this investigation is the one where celebrities and/or experts, as well as ordinary people are invited as the talk show guests to discuss a particular topic.

This paper approaches the notion of coherence from the perspective of Conversation Analysis (CA) in favor of a more empirically grounded approach to coherence. Geluykens (1997) following Crystal (1997) support this argument by defining that conversation analysis is a method of studying the sequential structure and coherence in conversations. In the local organization of conversation, interlocutors appear to reach agreement interactively on what they are talking 
about, and in doing so they create coherence as they go along. This study provides an analysis of discourse structure within television talk show through pragmatic framework for the description and interpretation of linguistic feature of talk show interaction as a mixed type of discourse in the context of media communication, and compare between English and Indonesian spoken talk show to clarify how different coherence is achieved in those talk shows.

The aims of this article is in line with the need of developing the discourse study in terms of linguistic point of view as well as bringing new development for communication studies, since discourse analysis used as well as conversation analysis incorporated in this study is related to social communication practice instead of individual perceptions.

The proposed cross-linguistic comparison of conversational strategies draws on the analysis of discourse, which is usually analyzed from conversational analysis in research studies. Discourse is stated as a two-way instrument, an instrument for a speaker and a listener or a writer and a reader, and it requires at least a sender, which can be a writer or speaker; a receiver, which is possibly a reader or a listener; and a message which is being transferred (Renkema, 1993). The message is functioning not merelyas connector between clauses, but it also formsa unified and coherent piece of discourse which is defined by an implicit agreement between the sender and the receiver (Nakatani, Hirschberg, \& Grosz, 1993; Louwerse \& Graesser, 2005).

The term coherence is not sufficiently defined by scholars in this field of discourse analysis; however, it basically refers to particular conceptsand relations which underlie its meaning. In other words, it is the connectedness within text (Renkema, 1993). Coherence should be made distinct from cohesion, since the latter refers to connection in the level of word and sentence structure (Louwerse \& Graesser, 2005) and much real language data displays coherence without cohesion (Gernsbacher \& Givon, 1995). Coherence in spoken discourse, then, involves more than lexical and grammatical links between elements in the text. It involves both intra and extra textual aspects. A spoken text can be called coherent if it follows particular indicators: the structure of adjacency pairs, turn-taking organization, how the speakers manage shifts and maintenance of topics during conversation, and repair (Brown and Yule, 1991).

Drew \& Heritage (1992) have pointed out that the aim of Conversation Analysis (CA) is to examine every detail of the data to identify the rules and devices used in the flow of conversation. Overall, CA is the study of recorded, naturally occurring talkin-interaction. Principally, it is designed to discover how participants understand and respond to one another in their turns of talk, with a central focus being on how sequences of actions are generated. For this reason, conversation analysis can be combined with discourse analysis to identify different coherence strategies in the talk show conversations.

The basic concept of a transition relevance in which coherence lies within is related with adjacency pairs, which is defined as having specific features such as two utterance length, adjacent positioning of component utterances, and different speakers producing each utterances (Schegloff and Sacks, 1973 cited in Ten Have, 2007, p.20). The conception within CA of particular linguistic constructions and other phenomena of language production can be seen from the turntaking organizations. There are various unit-types with which a speaker may set out to construct a turn. The unit-types include sentential, clausal, phrasal, and lexical constructions (Sacks et.al, 1978 cited in Ten Have, 2007, p.52). 
Text coherence, as derived by most linguists and experimental psychologists, is related to the behavior of text comprehenders. In spoken discourse, the same condition applies. There are some concrete textual elements which are easier to track to measure the coherence including referents, temporality, aspectuality, modality, location and action/script. However, the access to the shared knowledge which is the backdrop to the talk exchange also needs to be taken into consideration. Both aspects are analyzed in this present study. An interesting phenomenon in coherence is what is described by Givon (1995) as maximal coherence, which is colloquially known as repetition. In a conversation, repetition can occur within a speaker-turn or between speaker-turns. Other indicators of whether coherence is achieved in a conversation are the structure of adjacency pairs, which refers to turn-taking utterances by two speakers, the overlapping talk, and topic shift as well as topic maintenance during conversation, and repair. The last element describes how interactants in a conversation deal with speaking, hearing, or understanding problems. It is classified by who initiates the repair, by who resolves the problem, and by how it unfolds within a turn or a sequence of turn (Hutchby and Wooffitt, 2005).

In line with the above discussion, the present study tries to explore: (1) How different is the coherence occurs in Indonesian-spoken talk show from the English-spoken one? and (2) What strategies are used to achieve that coherent discourse?

\section{METHOD}

This article reports on the different approaches used by Indonesian and English talk show hosts. The analysis targets discourse strategies of the talk show's host as well as the contribution of the guest. In order to answer the research questions, the analysis in this study involves a range of approach. The approach taken here draws on research in conversation analysis and discourse analysis. This study identified some indicators of speakers achieving coherence through different strategies in talk show conversations, including adjacency pairs, turn-taking organization within the talk, topic-shifting, and what so called repair.

As Ragin (1994) mentioned, the general outline for research projects in conversation analysis would at least involve the four phases of getting or making recordings of natural interaction, transcribing the tapes, either in whole or in part, analyzing selected episodes and reporting the research. The data of this study was taken from an English talk show 'Oprah Winfrey Show' and an Indonesian talk show 'Kick Andy', which were gathered by transcribing two series of the talk shows, one episode for each language. One transcript was analyzed first to figure out the indicators of how speakers accomplish coherence; then, the same treatment was applied to the other talk show. The result was then compared one to another and conclusion will finally be drawn from the result of analysis.

It is expected that this study support the preliminary hypothesis that coherence is achieved in both English and Indonesian talk shows. Similar indicators showing that the conversation is coherent, such as adjacency pairs, might be found out; however, there are some others that will be slightly different within the Indonesian and English talk show as culture influences the way interactants speak.

\section{FINDING AND DISCUSSION Adjacency Pairs}

One of the most noticeable things about conversation is that certain classes of utterances conventionally come in pairs. For instance, questions and answers; greetings and return greetings; or 
invitations and acceptances or declinations. In both English and Indonesian extract of talk show conversation, the question and answer adjacency pairs are the most common phenomenon being found.
I first present results for adjacency pair sequence in English conversation and then that in Indonesian talk show conversation.

1 O: There was a time, I read, when you were actually thinking in this past 7 years, because you haven't

2 done an album since 2002, that you were thinking of, I read, going to an island and having a [fruit 3 stand?

$4 \mathrm{~W}$ :

Fruit

5 stand. Yap. I was thinking of having a fruit stand and growing organic fruit with my daughter on a

6 little island on the beach and everything, living the simple life.

Line 1-3 represents the first part of a question-answer adjacency pair. However, even when it has not been completed yet, the speaker $\mathrm{W}$ already knows what $\mathrm{O}$ is about to say; thus, there occurs an overlapping talk as well. The adjacency pairs sequence is question and answer with a purpose of confirming something.This type of adjacency pairs is the most likely phenomenon found in the English talk show conversation. Question-answer sequences signify that the mutual understanding is accomplished and displayed in the talk and thus, it builds the coherence within the spoken discourse.In the following is another adjacency pairs found which involves Yes/No Question

1 O: Was marrying Bobby a way to be out?

$2 \mathrm{~W}: \underline{\text { In a sense, }}$ because he allowed me to be me. He was fun. Passionate. Loving. It was crazy.

3 O: Do you know I interviewed him by myself?

4 W: Yeah, I know.

5 O: I only spent one hour with Bobby Brown. And in that one hour I could see that thing

6 W: That energy

7 O: That energy and how alluring that could be -

In this extract of conversation, the first part of a question-answer adjacency pair is completed first, and then the speaker stops. The next speaker then starts in line 2 . However, there is an interesting aspect here. In line 2 , the speaker $\mathrm{W}$ does not directly answer the question with yes or no, as what is actually required in a yes/no question sequence. Instead, she uses another phrase 'in a sense' to replace the 'yes' answer. The following excerpt also contains adjacency pairs involving yes/no question as well as WH question.

1 O: And they said you were, you know, if Disney on the big movie on their first black princess - you

2 were the first black princess - and so the princess marries the bad boy. Was that strategic on your 3 part?

4 W: It wasn't. It really wasn't. I was at the Soul Train awards show. He came on thestage singing My

5 Prerogative. He was fly. He could move, man.

6 O: What did he say to you? Were you first interested in him or he interested in you?

$7 \mathrm{~W}:$ He was interested in me.

8 O: Really. What did he say?

9 W: He was like, you know, Bobby was more like: "Hey, check this out, I want to ask you something',

10 you know. "If I was to ask you to go out with me, would you say yeah?"

$11 \mathrm{O}$ : And you....and you -

12 W: ((laugh)) And I said: "Yeah, I would. I certainly would." And then from that moment on, we clicked.

13 We were friends. Three years we went out before we got married. Three years we dated.

14 Jet-setted all over the world doing what we wanted to do. You know what I'm saying. 
In this part of conversation, the adjacency pairs are still about questionanswer asking for confirmation. Line 2 shows a yes/no question and it is adjacent to the answer 'no'. However, the speaker $\mathrm{W}$ prefers to mention ' $i t$ wasn' $t$ ' instead of just saying ' $n o$ ' as an answer. A clearer adjacency pair is provided in line 6 and 7 . In line 6, speaker $\mathrm{O}$ gives two options regarding W's relationship with her husband, who is attracted to another for the first time; and the second pair part (line 7) remains relevant in this case. The next adjacency pair within this instance of conversation is line 8 and 9 . The question in line 8 uses WH question, and the adjacent position (line 9) indicates that $\mathrm{W}$ as a second speaker understood what the prior speaker aimed at.

Ideally, the two parts in adjacency pairs should be produced next to each other to make it coherent for the interlocutors; however, as Hutchby (2005) explained, the parts of adjacency pairs do not need to be strictly adjacent at all. There are systematic insertions that can come between first and second pair parts. A question-answer pair can also be produced with an insertion sequence:

1 O: When did you know that that marriage was not gonna work?

2 W: I just knew. I was like, "You don't smell right. You don't look right. Something's going on." And then

3 all this other stuff started coming out about him being with this one or that one or being too

4 promiscuous $=$

5 O: Did that hurt you?

$6 \mathrm{~W}$ : =Dragging dirt into my home.

7 O: Did that hurt you? Were you offended by it?

8 W: It disturbed me. I was disturbed.

In this instance, speaker $\mathrm{O}$, in line 5, addresses a question, and when it is complete, the speaker stops, and the next speaker starts in line 6. However, what $\mathrm{W}$ produces (line 6) is not the second part of the pair but the completion of the previous pair. Thus, the question is repeated until the answer is produced. The answer in line 6 does not ignore or propose not to answer the question in line 5; rather, it acts to delay the answer.
There is another inferential aspect in adjacency pairs sequence stems which Hutchby (2005) called 'preference'. For instance, an offer can be accepted or refused, assessments can be agreed with or disagreed with; and requests can be granted or declined. It is different to produce acceptance, agreement, and granting compared with producing their negative alternatives. This is the organization of 'preference'. The following excerpt contains preference:

$1 \mathrm{~W}$ : At that point in time, or I thought. However, I wasn't remembering the gift that God had given

2 me. I had totally put all that aside. And my daughter was growing up before any eyes, and I just 3 wanted to grab hold of that.

$4 \mathrm{O}$ : Isn't it amazing how fast that happened?

$5 \mathrm{~W}$ : Yeah. And I said Oh my God. Because life is so fast and I wanted to watch her, I wanted to be the

6 parent. Well, at that point of time I was single parent and (1.5) watch her boarding school and when

7 she got home. Be there.

In this extract of conversation, the 'preferred' action is that the speaker $\mathrm{O}$ shows her agreement on W's statement by using the question tag marker isn't it. Moreover, this action is also inviting recipient agreement which is indicated by the word yeah. By contrast, there are some cases where a speaker 'dispreferred' what the previous speaker has mentioned, such as what is found in this instance 
1 O: Was he jealous of you?

2 W: Umm..well..he never liked the fact that people would say 'You're jealous of her. You're just jealous of her fame and her fortune and what she has, and everything, and he would get really pissed off. But it's not, it's not abnormal for a man to feel that way. Or to feel, you know, that he was lacking.

It can be observed that $\mathrm{O}$ appears to expect the answer 'yes' from W. However, $\mathrm{W}$ does not go along with the assumption implicit in O's turn. W's response is constructed differently so that it expresses an indirect dispreference. The response is formed up so that the disagreement is shown as weak as possible. An interesting aspect to look at is that $\mathrm{W}$ implicitly agrees with O's statement; however, the given response is contrasting. According to Sacks (1987), one of the most significant ways speakers have of indicating the dispreferred status of a turn is by starting the turn with markers such as 'well' or 'Um'. However, in this extract of conversation, W implicitly states an agreement to O's statement by using the phrase 'it's not abnormal to feel (jealous)', which, in fact, means 'yes'.

Indonesian talk show session, on the other hand, has the same type of adjacency pairs, question and answer. However, the questions addressed by the host are frequently answered with such a long explanation like in this following extract of conversation.In this extract of conversation, the host A asks $\mathrm{G}$, who is a reputable author, about what he wants to share from his books.

\footnotetext{
1 A: Dalam buku-buku anda, banyak sekali yah (.) anda menawarkan pemikiran-pemikiran, terus nilai filosofinyatinggi sekali ya. Saya termasuk pembaca beliau. Nah, apa yang ingin anda sampaikan melalui buku-buku anda?

4 G: Mau menjalankan panggilan kehidupan. Saya memulai profesi penulis sekitar 27 tahun yang lalu ketika

5 masih di SMA. Kala itu ada yang saya baca di koran itu, 'Manusia hidupnya tidak diselamatkan oleh

6 pendidikan, tapi diselamatkan oleh keterampilan'. Saat itu saya berpikir, apa nih keterampilan yang

7 harus saya kembangkan kalau mau hidup saya selamat. Sehingga satu-satunya pekerjaan yang saya

8 lakukan tanpa terputus selama 27 tahun itu, menulis.
}

1 A: In your books, lots of those, right (.) you offer ideas, and those are highly philosophical. I'm one of his 2 books readers. Well, what do you want to share from your books?

3 G: I am trying to fulfill the summons of life. I started to be an author since 27 years when I was still in high 4 school. At that time, I read a newspaper and there was written, 'Human's life is not saved by education, 5 but skill'. At that time I thought what skill I should develop if I want to be saved. So, the only job I've 6 done continuously for 27 years is writing.

Other adjacency pairs in the Indonesian talk show sessions can also be found in other turn-taking data. However, instead of simply formed as question and answer pattern, those tend to be an interview-like pair sequence, in which a question from the host is answered by such an explanation by the interviewee.As previously explained, the coherence of conversational interaction partially depends on our expectation that, according to the adjacency pair formula, what follows a question should be treated as an answer to that question. Thus, these parts of talk containing adjacency pairs are considered coherent.

\section{Turn-taking and Overlapping Talk}

The following extract may give illustration on overlapping talk orienting to turn-taking mode.

1 O: So we were talking about how you did light drugs before The Bodyguard and then after The

2 Bodyguard

3 W: Oh, got heavy. 
4 O: Heavy.

$5 \mathrm{~W}$ : because I knew then we were trying to hide pain

6 O: you were trying to hide

7 W: I was trying to hide pain. Yeah.

8 O: Because The Bodyguard which, to the world, was one of the biggest moments ever in the history

9 of CDs, albums and catapulted you to a level of stardom

10 W: Right. And remember I did waiting to Exhale after that, and then that album was huge.

11 O: And The - Preacher's Wife after that

12 W: $\quad$ and The Preacher's Wife.

This instance could be labeled initial transition relevance. O had not actually been about to finish her turn at the point when $\mathrm{W}$ projected its completion. The overlap occurs is not such a violation to O's turn to some extent. W projected a transition-relevance place at the end of what was a possibly complete turnconstruction unit by $\mathrm{O}$. The overlapped turn-taking in this extract of conversation supports the fact that overlapping is not always violating the turn-taking rules. Even though $\mathrm{O}$ has not finished her turn, $\mathrm{W}$ has already known the completion part of it.

Another phenomenon that can be found in this instance is that this excerpt might be coherent for two persons involved in the talk, but it can be incoherent for the audience. The audience has to possess a background knowledge related with 'The Bodyguard', 'Exhale' and 'The Preacher's Wife'. Audience needs to understand that those are the albums of movie soundtrack with the same title in which Whitney
Houston starred. Since Oprah Winfrey Show is a world-wide talk show and being watched by people all over the world, this part of talk show might be incoherent for some viewers in for instance, Indonesia. It is because the last two titles are not quite popular for Indonesian viewers, so it is possible that this turns to be less coherent for them. However, there is a helpful clue mentioned by $\mathrm{W}$ when she said 'I did waiting to Exhale after that, and then that album was huge' showing that it is a recording she is talking about.

Within the above excerpt of conversation, the overlapped talk is included in the recognitional onset, which occurs when the next speaker recognizes what current speaker is saying and can project its completion, since $\mathrm{W}$ has already had the completion of O's statement.Another turn-taking unit with overlap in it can be seen in this following instance:

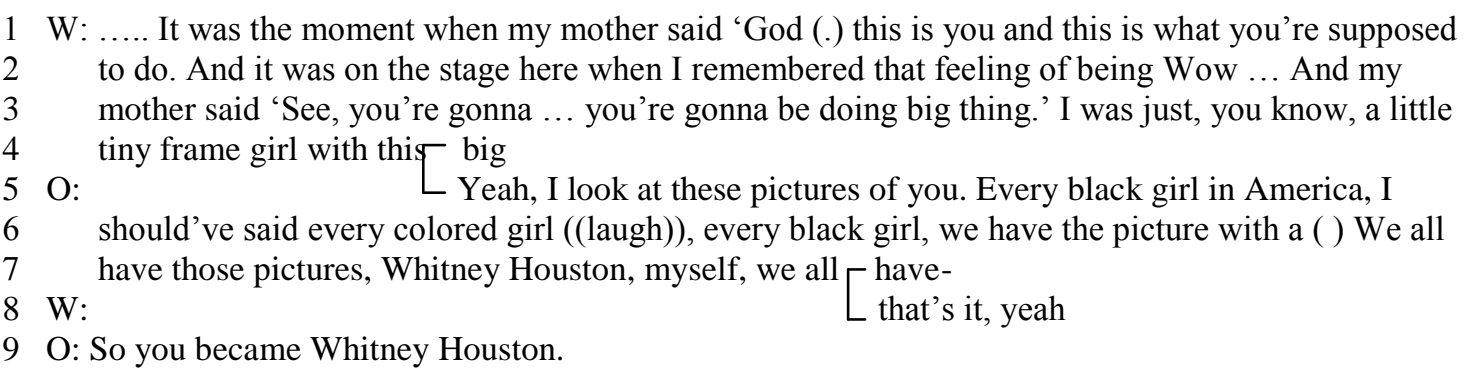

The overlap onset, which is marked by left-hand square brackets, shows an understanding that speakers display of each other's talk even though one speaker has not completed her turn yet. Overlapping talk can be found in many parts of the talk show conversation. In a turn-taking sequence, it is also possible that speakers use repetition in the turn to emphasize his/her purpose of utterance, such as in the following instance: 
1 W: because I was in control of all my stuff, and here he comes along and everybody was like,"Wow, she's

2 got somebody now." When he said something, I listened. You know, I was very interested in having

3 someone has that control over me. That kind of thing, you know, it was refreshing.

4 O: It was refreshing because in every other aspect of your life-

5 W: I was in control.

6 O: $\underline{\text { You were in control }}$

7 W: Yeah

8 O: So it was for you an opportunity to release control to someone else?

9 W: Yes. And then we had fun. He was fun. He taught me how to dance, how to move my hip ((laugh))

10 can describe it as (0.5) passion

In this extract of conversation, speaker $\mathrm{W}$ in line 3 mentioned that it was refreshing to have someone to control her, and the clause 'it was refreshing' is repeated by speaker $\mathrm{O}$ within her next turn. Line 5 and line 6 is in the same condition. Compared with English conversation in the data, the Indonesian talk show contains more overlapping talk. Overlaps occur in many other data. The following extract, for instance, represents how overlaps containing repetition are interpreted by coparticipants as coherent turns at talk.

1 S: Masih banyak orang yang memiliki banyak, demikian banyak kesulitan tapi mereka tetap punya

2 semangat juang yang tinggi. Begitu. Jadi alangkah piciknya kalau misalnya saya cuma nyari kerjaan ga

3 dapet-dapet terus jadi putus $\quad$ harapan gitu ya 4 A:

Lutus asa

5 S: Banyak, banyak sekali yang dialami orang yang jauh lebih er (.) lebih berat dari kita

6 A: Iya, berarti sedang bercerita tentang salah satu tokoh disitu, yang namanya Lintang $ᄃ$ ya

$7 \mathrm{~S}$ :

8 A: yang bersepeda 40 kilometer pulang pergi. Berarti $80 \mathrm{~km}$ setiap hari. Dengan sepeda butut yang

9 rantainya suka putus -

10 S: Iya betul

11 A: dan untuk $\Gamma$ mencapai sekolah

$12 \mathrm{~S}$ :

Leorang

13 A: Lintang ini harus menyeberang sungai yang ada buayanya. Jadi banyak betul tantangannya $\left[\begin{array}{l}\text { ya } \\ \text { Iya }\end{array}\right.$
S:

14 S:

1 S: There are still a lot of people who have a lot, a lot of difficulties in life but they can still have fighting 2-3 spirit. So, it is too shallow if I can't get a job then I become $\_$desperate

4 A:

L desperate

5 S: There are a lot, a lot of people had a more er (.) difficult problem than us

6 A: Right, so you're talking about one character in book, named Lintang, $\quad$ are you?

$7 \mathrm{~S}$ :

L Yes

8 A: who has to use his bike through 40 kilometers return. It means $80 \mathrm{~km}$ everyday. With an old bicycle

9 whose chain is broken -

10S: Yes. That's true.

11A: and to $\leftarrow$ reach school

12 S: L this

13A: this Lintang should cross the river which has crocodile in it. So he really faces challenges, $\square$ doesn't he $14 \mathrm{~S}$ :

The overlap onset in this excerpt of conversation indicates that speakers signal their acceptance of other's contributions to talk by their use of 'iya'('yes'), as is shown in line 6-7 and 13-14. Moreover, repetition of prior speaker's talk (line 3-4) signals

agreement which in turn, shows coherence. In the talk show conversation, both English and Indonesian, it is obvious that turntaking occurs all over the talk. Gaps and overlap also occurs quite a lot; however, the point is that the ideal conversation is 
the one which can cohere well. It means that there must be as much inter speaker coordination as possible, as what we can find in some previous excerpts of conversation.

\section{Repair}

Hutchby (2005) followingSacks, Schegloff, and Jefferson's (1978) work makes a distinction between the initiation of repair (marking something as a source of trouble), and the actual repair itself. In addition, there are also the distinction between repair initiated by self (the speaker who produced the troubled source), and repair initiated by other.A repair occurring in the English talk show is the repair in which the speaker of a trouble source may try and get the recipient to repair the trouble.

1 O: Well, one of the things that I recall in an interview that you did with Diane Sawyer in 2002, the world

2 was shocked when she asked you about addiction and you said if there was an addiction, it was an

3 addiction to making love.

4 W: Yes. We did a lot of that. Lots.

5 O: When did it start to go wrong? Can there be too much passion?

6 W: Yeah, it can clash. After The Bodyguard -

7 O: After? That was too early

This extract illustrates self-initiated other-repair. Speaker O asks about when the relationship between $\mathrm{W}$ and her spouse started to go wrong, and the second part of the adjacency pair states that it was after the movie 'The Bodyguard' was released. Speaker O then reconstructs the answer by stating 'that was too early', because the problem was supposed to occur far after the release of that movie, or probably after the next W's movie and album were released.Self-initiated self-repair which both trouble and repair are initiated and carried out by the speaker of the trouble source has also been found.

1 O: Did you realize what you were getting yourself into when you signed up for that?

2 W: I did not.

3 O: you did not?

4 W: No. No. (1.5) I knew when I signed my prenuptial, though. ((laugh)) I knew what I was doing there.

5 But, however, no, I didn't know. I was in love. I was crazy in love. It didn't matter to me.

Self-initiated self-repair here is constructed by speaker W. She gives negative answer toward O's question at the beginning, but then she tries to make a repair toward the answer she produced. The speakers were talking about whether $\mathrm{W}$ was aware what she was involved in when she signed the contract for a TV reality show, and $\mathrm{W}$ answered 'no'. However, she then revised her answer by comparing that to the time when she signed her prenuptial. What is interesting here is that she finally provides a repeat of the prior turn answer and thereby recycles the trouble source.In this conversation under investigation, there are not so much repair of one speaker by another speaker occurs in the English talk show. Meanwhile, there is no repair sequence can be found within the Indonesian talk.

\section{Topic Shifting and Topic Maintenance}

Within a turn-taking sequence in a conversation, topic shift is a common feature to be found. The way speakers maintain and shift from one topic to another can determine the topical coherence within the talk. In a session of Oprah Winfrey Show, for instance, in this following extract, the speakers were talking about how media affects W's life. The 
topic shift is indicated by the clause 'That's so interesting that you would say that'.

1 W: I knew in the days when I was a teenager singing for God. I was so sure. When I became "Whitney Houston" and all this other stuff that happened, my life became the world's. My privacy. My business. Who I was with. Who I married. Who I -

And I was, like, that's not fair. I wanted to go to the park. I wanted to walk down, you know, the street with my husband, hand in hand, without somebody looking at us or having the media always in my business. Saying what we are, and we weren't, saying what we're doing, and we weren't, or subjecting my daughter (.) while she was just born, she was - I just wanted to be normal. I had no normal 20s, I had no normal $30 \mathrm{~s}=$

9 O: I know

$10 \mathrm{~W}$ : =My life was just like kept making records, doing tours all around the world, or going to every place 11 and... and -

$12 \mathrm{O}$ : That's so interesting that you would say that because for years I have thought that, $\mathrm{mmm}$... in many ways, the Whitney Houston that we have seen has been a creation of the media. That obviously your voice and your talent is what it is. But the gowns, the hair, that first video, all of that stuff was a15 creation. You were really somebody else.

Topic shifting can take place with or without lexical marker, and during the talk the topic to build mutual understanding for both speakers as well as the audience. show sessions, the host keeps maintaining

$1 \mathrm{~W}$ : At that time in my life, I was going through much trauma. I had been through-, gone through-. I thought 2 that was enough for me. I had the money. I had the cars. I had the house. Had the husband. Had the 3 kid. And none of it was really that fulfilling. I mean, you know-

4 For a time, I was happy. I was happy, but I needed that joy. I needed my joy back. I needed that peace 5 that passesallunderstanding. I needed that (.) that moment (.) you know. I am saying that when I was

6 three years old, that 'Church' thing that my mother gave me when I was born into (0.5) I was looking

7 for - that mmm

8 O: $L$ where the spirit $[$ hits-

9 W: $\quad$ Y Yes.

10 O: that everybody has $\Gamma$ it

11 W: $\quad[$ Yes. And I thought it's really gone

12 O: The thing that happened (.) When we saw you in 1991 and you sang The Star Spangled Banner-

$13 \mathrm{~W}$ :

14 O: at the Super Bowl

15 W: exactly (.) exactly. I thought I had done anything that I was supposed to do, but no (.) there are a lot

16 more to go

17 O: So, tell me why you think that you're pretty much done it.

18 There's a wonderful quote by the L.A. Times. They said, "The pain, and frankly, disgust that so manypop 19 fans felt during Houston's decline was caused not so much by her personal distress as by her seemingly

20 careless treatment of the national treasure that happened to reside within her."

Here the speakers are talking about the past experience $\mathrm{W}$ had about her family, how she dealt with her traumatic experience. Topical coherence is achieved through the question-answer sequence. The topic is proposed in a statement (line 12: 'When we saw you in 1991 and you sang The Star Spangled Banner') instead of actual question. This topic-preparing sequence is then followed by the lexical marker 'so' indicating that speaker $\mathrm{O}$ changes her question related with new topic regarding why $\mathrm{W}$ felt done with her life and wanted to go back like she used to be (as a good singer). In comparison, the Indonesian talk show uses similar strategies to maintain topic and shift from one topic to another, as is shown in this instance. 
1 A: Jadi. Bisa cerita sedikit pengalaman hidup anda waktu kanak-kanak bersama dengan anggota laskar

2 yang lainnya?

3 SH: Waktu dulu kita memang ada keadaan sulit ya. Tapi kita tetap kerjasama er (.) sepuluh orang ini kita

4 tetap kompak. Jadi kalau ada masalah di luar memang suka kita rundingkan.

5 A: Tapi kalau saya lihat, hamper semua yang diwawancara itu terkesan sama Ibu Muslimah. Apa yang

6 anda ingat tentang ibu Muslimah ini?

$7 \mathrm{SH}$ : Dia, sebagai seorang guru yang benar-benar mendidik muridnya er (.) sangat disiplin. Kemudian

8 sesuai dengan kaidah agama yah.

9 A: Kenapa disebut 'laskar pelangi' ya?

10 AH: Eh, ketika itu saya belum sadar, ketika beliau memanggil kami 'laskar pelangi', maksud yang

11 tersembunyi di balik panggilan itu. Tapi setelah saya dewasa, sekarang saya mengerti bahwa beliau itu

12 mengobarkan semangat kami. Dengan kata 'laskar' itu yah. Karena laskar kan pejuang.

1-2 A: So, can you tell us a bit of your childhood experience with the members of laskar pelangi?

$3 \mathrm{SH}$ : We used to have difficult condition. But we could cooperate well er (.) these ten people are still united.

4 So, we often discuss about many issues at that time.

5 A: But I can see that almost everyone being interviewed (in the VT) is impressed with Ibu Muslimah. What 6 can you recall about her?

7-8 SH: As a teacher, she is really er (.) discipline. Also use the religion basis when she teaches.

9 A: Why was it called 'laskar pelangi'?

$10 \mathrm{AH}$ : Er, at that time I haven't realized yet, when she called us 'laskar pelangi', what is the meaning

11 behind that name. But after I grew up, I now understand that she tried to excite our spirit. With the word

12 'laskar'. Because it means fighter/warrior.

This exchange shows that the host, from the questions he delivered to the guest, tries to keep the topic not to get off the track. The shifting he makes from questioning about childhood experience then the history behind the name 'LaskarPelangi' itself is inserted by discussing about SH's teacher, IbuMuslimah. This, in turn, builds up the topical coherence within the talk.

As Langford (1994) pointed out, it is observed that speakers appear to be interacting coherently; meaning that they are aware of local organization in conversation, when trouble-shots occur so that they need to construct a repair on that, so they are usually quickly resolved. Turntaking organization in both English and Indonesian-spoken talk shows are similar, in terms of adjacency pair sequences occur in those two talk shows. Overlapping, as one of the most common features in a conversational interaction also occur frequently in both talk shows.

The results reported in the previous section permit the following answers to the research questions for this study. When different speakers produce two utterances, when positioned in the second adjacent position, a speaker can show that he understood what a prior speaker aimed at, and that he is willing to go along with that. Here is the importance of coherence; to build mutual understanding between speakers in a sequence of talk. Participants can use the adjacency pair mechanism to display to one another, and their ongoing understanding and sense-making of one another's talk; thus, it builds a coherent talk. By their nature, questions addressed in the talk shows are interactive since they form the first part of a question-answer adjacency pair. When the host asks a question which attempts to trigger a new topic, chances of success are relatively high, because the interviewee will be expected to respond appropriately with the second part of adjacency pair.

An important point to note is that some classes of utterances are conventionally paired so that when the first pair part is produced, the second part become relevant and remains relevant even though it is not produced in the next serial turn. Even though it is argued that the next turn in an adjacency pair sequence is a relevant 
second pair part, it does not strictly need to be the next turn in the series of turn which makes up some particular conversation. In the English talk show conversation being analyzed, the most common sequence to be found is the question and answer sequence, without any insertion. Meanwhile, the Indonesian talk show contains the same features, but it has relatively longer question-answer sequence.

Coherence is an important factor to look at how participants in a spoken discourse display for one another their understanding of 'what is going on'. This is what underlies the focus of sequences: throughout the course of a conversation or other talk-in-interaction, speakers display in their sequentially next turns an understanding of what the prior turn was about. That understanding may turn out to be what the prior speaker intended, or may not be, that itself is something which gets displayed in the next turn in the sequence, which seems to be more like segment of interview though not the structured interview.

Turn-taking model begins from the idea that in a conversation, the turns are distributed in systematic ways among speakers. As stated by Hutchby and Wooffitt (2005), there are three fundamental facts about conversation; the first one is that turn-taking occurs. Consequently, one speaker tends to talk at a time, which is considered the second fact. The third basis is that turns are taken with as little gap or overlap between them as possible. The taking turn and the way speakers maintain the turn as well as the topic indicate that the sequence of talk are coherent. With the talk show conversation under investigation, there is a regular relationship between the places where overlap begins (overlap onset), and the completion of turn constructional unit. This confirms Coates' (1995) study that the overlap is not haphazard but can be seen to be related to the recognition of a point of possible completion of a turn. The topic framework represents the area of overlap in the knowledge shared by the participants at a particular point in a discourse. The way hosts maintain the topic (book review in Indonesian talk show and W's life experience in the English one) enables us to make judgment of relevance with regard to conversational contribution. It means that the interlocutors are speaking topically and building coherent talk.

There is also an interesting phenomenon related with participants' orientation to conversational device which is called continuer. Recipient should recognize the compound nature of the device. This means that the device takes more than one turn-construction unit to produce. Like at the beginning of Oprah show, the word 'yes' may be seen as a continuer, which display a recipient understanding that a turn-in-progress is not complete, even though a possible transition-relevance place may have been reached. As Schegloff (1982 cited in Hutchby and Wooffitt, 2005, p.106) said, continuers act to bridge turn-construction unit, and show their producers passing on what is possible opportunity to take turn. Using this analysis, the continuer has function as a bridge between the first part and second part of sentence. In the Englishspoken talks show, speaker $\mathrm{W}$ frequently uses the phrases like 'you know', 'I mean', and 'you know what I'm saying'. It can be argued that these phrases determine coherent in terms of making sure that the mutual understanding between one speaker and the interlocutors is preserved.

Both talk shows, in fact, share the similar indicators and use similar strategies in order to achieve coherence across the talk show sessions; however, there has been found a slight different phenomenon within the selected episodes of the talk shows. Speaker's hesitation is found more in the Indonesian talk show instead of the English one. It is commonly known that 
hesitation is an unavoidable in any kind of conversational interaction. However, within the two talk shows being analyzed, its occurrence is more often found within the Indonesian talk show. However, cultural difference is not a defining factor that differentiates the coherence built in English talk show from the Indonesian one. This is in line with the result of Moerman's study (1988) which demonstrates that similar patterns of talk-in-interaction exist in different cultures and distinct languages.

\section{CONCLUSION}

This paper has tried to show how conversational coherence is achieved within talk shows, what strategies used by both host and interviewee to achieve coherence collaboratively. It was shown that in both English and Indonesian talk shows, conversational activity of asking questions can be employed to measure a coherence of a stretch of conversation. Question-answer adjacency pairs can provide the framework through which coherence is achieved, and they have two possibilities to be agreed or disagreed with. This is clear from the English talk show instead of the Indonesian one. The way speakers taking turn and the occurrence of overlap within the sequence of conversation can also determine mutual understanding among the participants. However, the Indonesian talk show offers a longer answer pair compared with the English one.

Overlap onset, as another marker of coherence, also occurs a lot in both talk shows. The way speakers (host and interviewee) maintain the topic throughout the talk supports the notion that mutual understanding is successfully achieved. Meanwhile, culture, which is assumed to determine different ways of maintaining the flow of the talk, is considered not too influential. Both talk shows use similar patterns with no significant difference in terms of culture. They differ only in the level of conversational devices used which is related to language use instead of cultural background.

This paper of course cannot present a complete picture of conversational coherence since it is limited to two particular talk show episodes and only found one conversational device namely questioning, as a very basic framework in the notion of coherence. Further studies will hopefully provide us with a more complete picture of the variety of strategies interlocutors use for creating topical coherence through the turn-taking system.

\section{REFERENCES}

Brown, G. and Yule, G..(1991).Discourse analysis. Cambridge: Cambridge University Press.

Coates, J. (1995). The negotiation of coherence in face-to-face interaction: Some examples from the extreme bounds. In M. A. Gernsbacher\& T. Givon (Eds.), Coherence in spontaneous text. Amsterdam/Philadelphia: John Benjamins.

Coulmas, F. (1997).The handbook of sociolinguistics. Cambridge: Blackwell.

Drew, P.\& Heritage, J. (1992).Analysing talk at work: an introduction. In Paul Drew \& John Heritage (Eds.) Talk at work: Interaction in institutional settings(pp.365). Cambridge: Cambridge University Press.

Fairclough, N. (1992). Discourse and social change, Cambridge: Polity Press.

Geluykens, R. (1997). It takes two to cohere: The collaborative dimension of topical coherence in conversation, In Bublitz etal. (Eds.), Coherence in Spoken and Written Discourse. Amsterdam/Philadelphia: John Benjamins.

Gernsbacher, M. A \&Givon, T. (1995). Coherence in spontaneous text (Eds.). Amsterdam/Philadelphia: John Benjamins.

Givon, T. (1995). Coherence in text vs. coherence in mind.In M. A. Gernsbacher\& T. Givon (Eds.), Coherence in spontaneous text.Amsterdam/Philadelphia: John Benjamins. 
Hutchby, I. (1995). Aspect of recipient design in expert advice-giving on call-in radio. Discourse Processes 19(2), pp. 219-238.

Hutchby, I. (2006).Media talk: Conversation analysis and the study of broadcasting. Glasgow: Open University Press.

Hutchby, I.\&Wooffitt, R. (2005). Conversation analysis: Principles, Practices and applications. Cambridge: Polity Press.

Ilie, C. (1999). Semi-institutional discourse: The case of talk shows, Journal of Pragmatics, 33, (2001), pp. 209-254.

Langford, D. (1994).Analysingtalk. London: Macmillan.

Louwerse, M.M. \& Graesser, A.C. (2005). Coherence in discourse. In Strazny, P. (eds.), Encyclopedia of linguistics(pp. 216-218), Chicago: Fitzroy Dearborn.

Moerman, M. (1988). Talking culture: Ethnography and conversation analysis. Philadelphia: University of Pennsylvania Press.

Morizumi, F. (1997). Managing distances: Discourse strategies of a TV talk show host,Edinburgh Working Papers in Applied Linguistics, 8, pp.63-75.

Nakatani, C. H., Hirschberg, J.,\& Grosz, B. J. (1993). Discourse Structure in Spoken Language; Studies on Speech Corpora. Retrieved April 2, 2009, from http://www.eecs.harvard.edu/grosz/papers/Discourse_Struc_in_langua ge.ps

Ragin, C.C. (1994).Constructing social research: The unity and diversity of method.Thousand Oaks, CA: Pine Forge Press.

Renkema, J. (1993).Discourse studies: An introductory textbook. Philadelphia: John Benjamins.

Sacks, H., Schegloff, E.A, and Jefferson, G. (1978). A simplest systematic for the organization of turn-taking for conversation. Language, 50, pp. 696-735.

Takagi, S. (2008).Incorporating critical factors into discourse analysis: An analysis of interviewing strategies in a TV talk show,Journal of Language and Culture; Language and Information, 3, pp. 71-88.

Ten Have, P. (2007).Doing conversation analysis: A practical guide. London: SAGE Publications. (First edition, 1999)
Tolson, A. (2001). Talking about talk: The academic debates. In Andrew Tolson, (Eds.) Television talk shows: Discourse, performance, spectacle (pp. 7-30). Marwah, NJ/London: Lawrence Erlbaum Associates.

Wardhaugh, R. (1986).An introduction to sociolinguistics. Cambridge: Basil Blackwell. 